\title{
Hydrogen production by supercritical water gasification of food waste using nickel and alkali catalysts
}

\author{
B. Amuzu-Sefordzi, J. Huang \& M. Gong \\ College of Environment, Hohai University, China
}

\begin{abstract}
Supercritical water gasification ( $\mathrm{SCWG)}$ of food waste was carried out with nickel and alkali catalysts $\left(\mathrm{NaOH}, \mathrm{KOH}, \mathrm{Ca}(\mathrm{OH})_{2}, \mathrm{Na}_{2} \mathrm{CO}_{3}, \mathrm{NaHCO}_{3}\right.$ and $\mathrm{K}_{2} \mathrm{CO}_{3}$ ). The food waste was comprised of a variety of food items. The experiment was performed in a batch reactor at supercritical water (SCW) conditions of $400^{\circ} \mathrm{C}$ and $22.1 \mathrm{MPa}$ for $10 \mathrm{mins}$. Hydrogen $\left(\mathrm{H}_{2}\right)$ gas yield regarding the use of the catalysts was in the sequence; $\mathrm{Ni}-\mathrm{K}_{2} \mathrm{CO}_{3}>\mathrm{Ni}-\mathrm{NaOH}>$ $\mathrm{Ni}-\mathrm{KOH}>\mathrm{Ni}-\mathrm{NaHCO}_{3}>\mathrm{Ni}>\mathrm{Ca}(\mathrm{OH})_{2}>\mathrm{Ni}-\mathrm{Na}_{2} \mathrm{CO}_{3}>$ No catalyst. The results of this study indicate that using $\mathrm{Ni}$ was effective to support the steam reforming reaction. However its effects on the water gas shift reaction (WGSR) was little. Also carbon dioxide $\left(\mathrm{CO}_{2}\right)$ was the predominant gas product in the presence of metal carbonates and bicarbonate. As a result, $\mathrm{H}_{2}$ selectivity was in the sequence, $\mathrm{Ni}-\mathrm{NaOH}>\mathrm{Ni}-\mathrm{KOH}>\mathrm{Ni}-\mathrm{K}_{2} \mathrm{CO}_{3}>\mathrm{Ni}-\mathrm{Ca}(\mathrm{OH})_{2}>\mathrm{Ni}>\mathrm{Ni}-\mathrm{Na}_{2} \mathrm{CO}_{3}>\mathrm{Ni}-$ $\mathrm{NaHCO}_{3}>$ No catalyst. Furthermore, using $4 \mathrm{~g}$ of $\mathrm{NaOH}$ was effective to shift the WGSR forward to produce a higher $\mathrm{H}_{2}$ yield and selectivity than when $4 \mathrm{~g}$ of $\mathrm{Ni}$ was used. However, when equal amounts of $\mathrm{Ni}$ and $\mathrm{NaOH}$ were used, the conversion of food waste into gaseous products was necessary to produce more $\mathrm{H}_{2}$ during the WGSR.

Keywords: hydrogen, food waste, nickel, alkali catalysts, water gas shift reaction, carbon dioxide, $\mathrm{NaOH}$, selectivity, supercritical water, gaseous products.
\end{abstract}

\section{Introduction}

Biomass (energy crops, agricultural residue, forest waste and residue and municipal solid waste) is one of the most abundant renewable energy resources. 
Biomass's energy potential is addressed to be the most promising among the renewable energy sources due to its wide spread and availability worldwide [1]. Producing $\mathrm{H}_{2}$ from biomass is considered to be sustainable and carbon-neutral since the $\mathrm{CO}_{2}$ generated is consumed during photosynthesis [2-9].

Over the past decade, SCWG has proven to be the most suitable method to produce higher $\mathrm{H}_{2}$ yields [10] from biomass with moisture content greater than $75 \%$ [11]. That is, the cost incurred in the drying of feedstock (biomass) in other methods such as pyrolysis is avoided [2]. During SCWG, organic compounds are converted into gases containing $\mathrm{H}_{2}$, methane $\left(\mathrm{CH}_{4}\right)$, carbon monoxide $(\mathrm{CO})$ and $\mathrm{CO}_{2}[11,12]$. Water at this point has a low density and a low dielectric constant therefore increasing the solubility of organic molecules at this stage [11-17]. The C-H covalent bonds are broken down to form carbon oxides and $\mathrm{H}_{2}$ [11] in a process referred to as steam reforming [2, 17-19]. However, the carbon monoxide $(\mathrm{CO})$ in the reactor further reacts with water to produce $\mathrm{CO}_{2}$ and more $\mathrm{H}_{2}[2,15,16,20-22]$. This reaction is known as the water gas shift reaction (WGSR). Due to the difference in $\mathrm{C}-\mathrm{H}$ bond in organic compounds, their solubility and liberation of $\mathrm{H}_{2}$ varies at $\mathrm{SCW}$ conditions. Moreover, at the same temperature and pressure, some organic compounds release more $\mathrm{H}_{2}$ than others.

The chemical structure of food waste is an important factor in influencing the resistance or otherwise of samples to convert into intermediates relevant for $\mathrm{H}_{2}$ gas production [23]. Food waste [24, 25] and other biomass feedstock [26, 27] have complex compositions that typically comprise of carbohydrates, proteins and fats and oils [28]. Thus, there is a ton of literature on the hydrothermal (subcritical and supercritical) gasification of model compounds (cellulose, glucose, xylan, glycerol, p-cresol and phenol) to simulate the conversion of real food waste for $\mathrm{H}_{2}$ production [29]. It is worth knowing that there are catalysts that influence the formation of certain product gas components [30] and also inhibit the formation of tar and char at considerably low temperatures [30, 31].

Transition metals such as $\mathrm{Ni}, \mathrm{Pt}, \mathrm{Ru}$ and $\mathrm{Rh}$ accelerate the steam reforming and the cleavage of $\mathrm{C}-\mathrm{O}$ and $\mathrm{C}-\mathrm{C}$ bonds during SCWG of biomass [15, 29]. These catalysts are therefore used to overcome energy barriers for low temperature SCWG. However, Ni is widely used due to its affordability. Also at SCW conditions, $\mathrm{H}^{+}$and $\mathrm{OH}^{-}$ions are liberated at high concentrations which creates a perfect condition favorable to acid-base catalysts during the WGSR [32-34]. Therefore, alkaline homogeneous catalysts such as $\mathrm{KOH}, \mathrm{NaOH}$, $\mathrm{K}_{2} \mathrm{CO}_{3}$ and $\mathrm{Na}_{2} \mathrm{CO}_{3}$ can promote biomass gasification for effective $\mathrm{H}_{2}$ production [15]. For instance, the addition of $\mathrm{KOH}$ increases the $\mathrm{H}_{2}$ and $\mathrm{CO}_{2}$ yield [15]. In the absence of a catalyst, the WGSR has been demonstrated to be accelerated by system pressure [35].

This study seeks to discriminate the combined effects of $\mathrm{Ni}$ and alkali catalysts $\left(\mathrm{NaOH}, \mathrm{KOH}, \mathrm{Ca}(\mathrm{OH})_{2}, \mathrm{Na}_{2} \mathrm{CO}_{3}, \mathrm{NaHCO}_{3}\right.$ and $\left.\mathrm{K}_{2} \mathrm{CO}_{3}\right)$ on $\mathrm{H}_{2}$ yield during the SCWG of real food waste at $400^{\circ} \mathrm{C}$ and 22.1 MPA for 10 mins. Therefore the objective of this study is to find the best $\mathrm{Ni}$ and alkali catalyst combination there is and the right proportion that will produce the highest $\mathrm{H}_{2}$ rich gas from this type of food waste. It is important to note that this literature only focuses on $\mathrm{H}_{2}$ yield and does not highlight details of liquid and solid residue. 
Also this study will serve as a baseline for further studies regarding food waste of multiple constituents to juxtapose other studies that use one food waste item under similar conditions.

\section{Materials and method}

\subsection{Raw materials}

The food waste used in this study was provided by the Hohai University's student's cafeteria, Nanjing, China. It was stored in a refrigerator at $4{ }^{\circ} \mathrm{C}$ prior to use. The constituents of the food waste are shown in Table $1 . \mathrm{Ni}, \mathrm{NaOH}, \mathrm{KOH}$, $\mathrm{Ca}(\mathrm{OH})_{2}, \mathrm{Na}_{2} \mathrm{CO}_{3}, \mathrm{NaHCO}_{3}$ and $\mathrm{K}_{2} \mathrm{CO}_{3}$ catalysts were supplied by Sinopharm Chemical Reagent Co. Ltd. All of these reagents were analytically pure. The water content and proximate and ultimate analysis are shown in Table 2. Carbon (C), $\mathrm{H}_{2}$, and Nitrogen (N) were detected using the Vario MICRO Elementar. To determine the water content $10 \mathrm{~g}$ of the food waste was placed in an oven at $105^{\circ} \mathrm{C}$ for $24 \mathrm{hrs}$ and weighed afterwards to calculate the water loss.

Water content

$$
W C=\frac{M w-M d}{M w} * 100 \%
$$

where, WC is water content, Mw is mass of wet food waste, Md is mass of dry food waste.

Table 1: Constituents of food waste.

\begin{tabular}{|l|l|l|l|}
\hline Grains/tubers & Vegetables & Protein/fats & Others \\
\hline Rice & Onions & Pork & dumplings \\
\hline Corn & Green pepper & Chicken & Fried egg \\
\hline Sweet potato & Red pepper & Beef & Bean sprout \\
\hline Potato & Green leaves & Cooking oil & Dried bean curd \\
\hline Vermicelli & Red radish & & Bean curd puff \\
\hline & White radish & & Pork sausage \\
\hline & Kelp & & Rice noodles \\
\hline & Shiitake mushroom & & \\
\hline & Enoki mushroom & & \\
\hline & Agaric & & \\
\hline & Cabbage & & \\
\hline & Broccoli & & \\
\hline & celery & & \\
\hline
\end{tabular}

\subsection{Reactor system and experimental procedure}

Food waste was pretreated by blending five times in a food waste disposer supplied by Diao Gong mao Gongsi Co. Ltd. It was further sieved with a $0.5 \mathrm{~mm}$ mesh in order to facilitate efficient gasification. SCWG of food waste was performed by using a $316 \mathrm{~L}$ stainless steel batch reactor that was obtained from the Songling Chemical Instrument Co., Yantai, Shandong, China. The schematic 
Table 2: $\quad$ Proximate and ultimate analysis for food waste sample.

\begin{tabular}{|l|l|l|l|l|l|l|l|l|}
\hline Sample & $\begin{array}{l}\text { Moisture } \\
\text { content }\end{array}$ & \multicolumn{3}{|l|}{ Proximate analysis ${ }^{\mathrm{a}}$} & \multicolumn{3}{|l|}{ Ultimate analysis $^{\mathrm{a}}$} \\
\hline & & $\begin{array}{l}\text { Volatile } \\
\text { Matter }\end{array}$ & $\begin{array}{l}\text { Fixed } \\
\text { Carbon }^{\mathrm{b}}\end{array}$ & Ash & $\mathrm{C}$ & $\mathrm{H}$ & $\mathrm{N}$ & $\mathrm{O}^{\mathrm{b}}$ \\
\hline $\begin{array}{l}\text { Food } \\
\text { waste }\end{array}$ & 81.5 & 93 & 1.5 & 5.5 & 46.36 & 6.98 & 1.86 & 39.3 \\
\hline
\end{tabular}

${ }^{\mathrm{a}}$ Weight percent of dry basis.

${ }^{\mathrm{b}}$ By difference.

of the reactor is illustrated in Figure. 1. The reactor has a $100 \mathrm{~mL}$ capacity and a maximum operating temperature and pressure of $650^{\circ} \mathrm{C}$ and $35 \mathrm{MPa}$, respectively. The reactor was heated by a salt-bath furnace that was fit with a PID temperature control unit with a K-type thermocouple.

The reaction pressure (which was not adjusted manually) was read from a pressure gauge (fitted to the top of the reactor) and depended on the reaction temperature and the water loading in the reactor. In this experiment, the reactor pressure was above $22.1 \mathrm{MPa}$ at $400^{\circ} \mathrm{C}$ when $33 \mathrm{~mL}$ of water was in the reactor, which indicated that the water achieved supercritical conditions at this temperature. At the head of the reactor is fitted a gas sampling tube with two high-pressure valves. This is used for gas sampling at the end of the reaction.

$40.5 \mathrm{~g}$ of food waste and a total of $4 \mathrm{~g}$ of catalysts were placed in the reactor. After the reactor was sealed, it was dipped into a $400^{\circ} \mathrm{C}$ salt-bath furnace that had an average heating rate of $10.6^{\circ} \mathrm{C} / \mathrm{min}$. Once the reaction temperature was reached, the temperature was maintained for $10 \mathrm{mins}$. At the end of each experiment, heating was stopped and the reactor was removed from the salt-bath before rapidly cooling to room temperature with cooling water and fans. The reactor was subsequently allowed to stand for $60 \mathrm{~min}$ to allow the gas to stabilize. After cooling, the final ambient temperature and pressure were noted. The gas outlet valve was opened to collect the gas sample.

\subsection{Gas analysis}

Effluent gas was sampled through a syringe $(20 \mathrm{~mL})$ with a three-way stop. These gas samples were analyzed with a gas chromatograph (GC5890) that was equipped with a thermal conductivity detector (TDX-01 packed column) and a flame ionization detector (PLOT $\mathrm{Al}_{2} \mathrm{O}_{3} / \mathrm{S}$ column) to determine $\mathrm{H}_{2}, \mathrm{CO}, \mathrm{CH}_{4}$ and $\mathrm{CO}_{2}$. The generated gas volume was measured by the displacement amount of the saturated sodium hydrogen carbonate (see Fig. 1).

\section{Results}

From Fig. 2, $\mathrm{H}_{2}$ yield from the various reactions was in the sequence, $\mathrm{Ni}-\mathrm{K}_{2} \mathrm{CO}_{3}$ $>\mathrm{Ni}-\mathrm{NaOH}>\mathrm{Ni}-\mathrm{KOH}>\mathrm{Ni}-\mathrm{NaHCO}_{3}>\mathrm{Ni}>\mathrm{Ca}(\mathrm{OH})_{2}>\mathrm{Ni}-\mathrm{Na}_{2} \mathrm{CO}_{3}>\mathrm{No}$ catalyst. The effects of combining $\mathrm{Ni}$ and $\mathrm{K}_{2} \mathrm{CO}_{3}$ gave the highest $\mathrm{H}_{2}$ yield of 


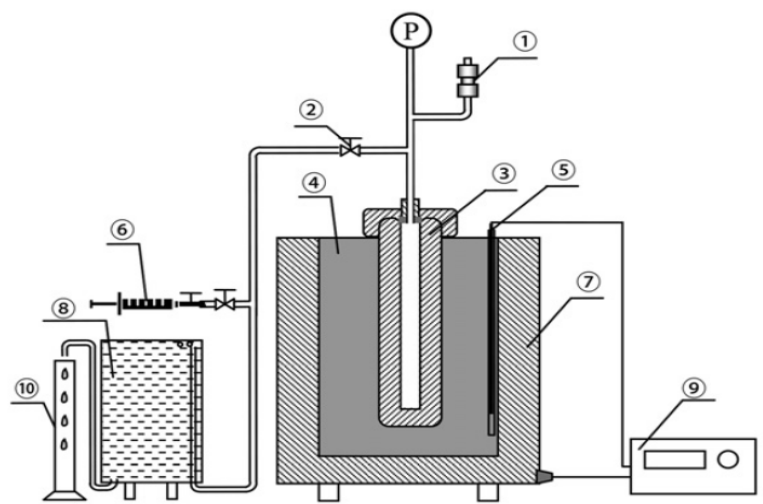

(1): Explosion-proof valve; (2): Valve; (3): Autoclave; (4): $100 \% \mathrm{KON}_{3}$;

(5): K-type thermocouple; (6): $20 \mathrm{ml}$ of syringe; (7): Salt-bath furnace;

(8): Saturated sodium carbonate solution; (9): Control system;

(10): Measuring cvlinder: P: Pressure transducer

Figure 1: Experimental apparatus.

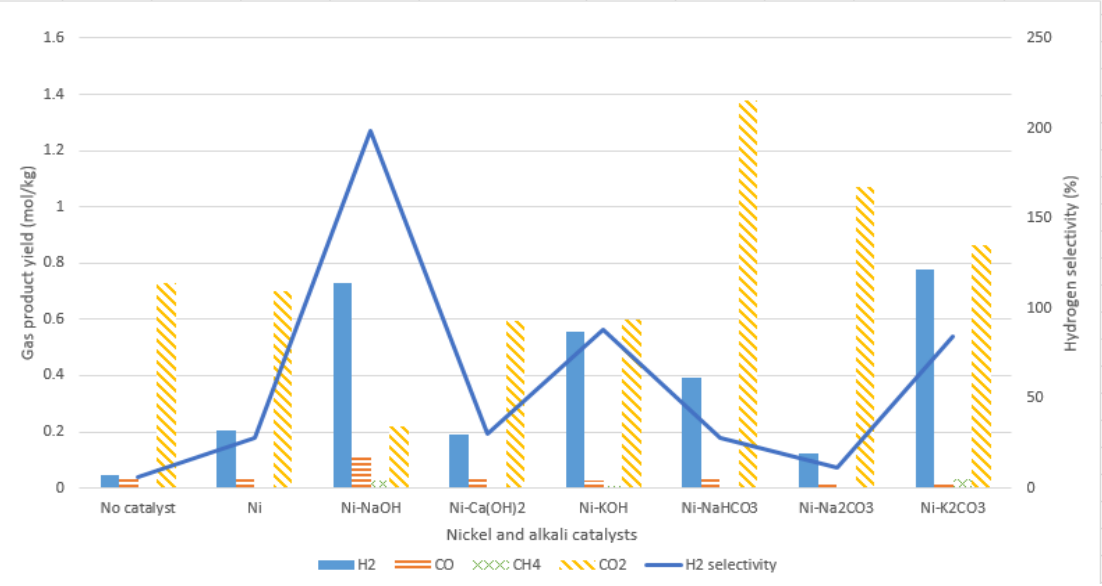

Figure 2: Gas product yield and hydrogen selectivity when $40.5 \mathrm{~g}$ of food waste was gasified for $10 \mathrm{mins}$ at $400^{\circ} \mathrm{C}$ and $22.1 \mathrm{MPa}$ using $\mathrm{Ni}$ and alkali catalysts.

$0.77 \mathrm{~mol} / \mathrm{kg}$, which is about 4 times more than the $\mathrm{H}_{2}$ yield when only Ni catalyst was used. SCWG of only food waste produced the least $\mathrm{H}_{2}$ gas yield $(0.04 \mathrm{~mol} / \mathrm{kg})$ recorded. Furthermore, the effects of $\mathrm{Ni}-\mathrm{Na}_{2} \mathrm{CO}_{3}$ and $\mathrm{Ni}-\mathrm{Ca}(\mathrm{OH})_{2}$ on $\mathrm{H}_{2}$ yield were relatively low. From Fig. 2, there is not a significant distinction between hydroxides and carbonates regarding $\mathrm{H}_{2}$ yield. However higher $\mathrm{CO}_{2}$ yields $(>0.8 \mathrm{~mol} / \mathrm{kg})$ were produced when $\mathrm{Ni}$ and carbonates/bicarbonate 
catalysts were used. Whereas combining $\mathrm{Ni}$ and hydroxides catalysts showed relatively lower yields of $\mathrm{CO}_{2}$ gas. Using equal amounts of $\mathrm{Ni}$ and $\mathrm{NaOH}$ produced the lowest $\mathrm{CO}_{2}$ gas of $0.22 \mathrm{~mol} / \mathrm{kg}$. This observation showed that the gas produced by $\mathrm{Ni}-\mathrm{NaOH}$ catalysts was rich in $\mathrm{H}_{2}$ although $\mathrm{Ni}-\mathrm{K}_{2} \mathrm{CO}_{3}\left(\mathrm{CO}_{2}\right.$ yield was $0.87 \mathrm{~mol} / \mathrm{kg}$ ) recorded a slightly higher $\mathrm{H}_{2}$ yield. The $\mathrm{CO}$ content of the gases produced from this experiment was very low and was in the range of 0.01$0.06 \mathrm{~mol} / \mathrm{kg}$. Also $\mathrm{CH}_{4}$ gas was the least detected in this study. $\mathrm{CH}_{4}$ gases detected were in the range of $0.001-0.027 \mathrm{~mol} / \mathrm{kg}$.

Furthermore, the amounts of $\mathrm{Ni}$ and $\mathrm{NaOH}$ were varied in the reactor to determine the right amounts of the two catalysts that will produce the best $\mathrm{H}_{2}$ rich gas. From Fig. 3, decrease in the amounts of $\mathrm{Ni}$ in the reactor showed significant increase in the $\mathrm{H}_{2}$ yield. However decreasing the amounts of $\mathrm{Ni}$ did not show any pattern regarding the $\mathrm{H}_{2}$ yield, in that, at a $\mathrm{Ni}$ to $\mathrm{NaOH}$ ratio of 1:3, there was a decline in the $\mathrm{H}_{2}$ yield as compared to the steady increase from reactions with $100 \%, 75 \%$ and $50 \%$ Ni. Moreover, the highest $\mathrm{H}_{2}$ yield $(0.9 \mathrm{~mol} / \mathrm{kg})$ was recorded when food waste was gasified with $100 \% \mathrm{NaOH}$. This reaction also recorded the lowest $\mathrm{CO}_{2}$ content signifying the most efficient reaction for $\mathrm{H}_{2}$ production in this study. Also the inhibition of $\mathrm{CO}_{2}$ production did not show a definite pattern with the different amounts of $\mathrm{Ni}$ and $\mathrm{NaOH}$ in the reactions but generally $\mathrm{CO}_{2}$ production was significantly inhibited with a more than $50 \%$ decrease in the amounts of $\mathrm{Ni}$ loaded in the reactor. However, a $25 \%$ decrease in the amounts of $\mathrm{Ni}$ recorded the highest $\mathrm{CO}_{2}$ yield of $0.88 \mathrm{~mol} / \mathrm{kg}$. Furthermore, methane production was very low, $(0.004-0.027 \mathrm{~mol} / \mathrm{kg})$. SCWG of food waste with $4 \mathrm{~g}$ of only $\mathrm{Ni}$ recorded the lowest methane gas yield of $0.004 \mathrm{~mol} / \mathrm{kg}$. Also gasifying food waste with equal amounts of $\mathrm{Ni}$ and $\mathrm{NaOH}$ recorded the highest $\mathrm{CO}$ yield $(0.118 \mathrm{~mol} / \mathrm{kg})$.

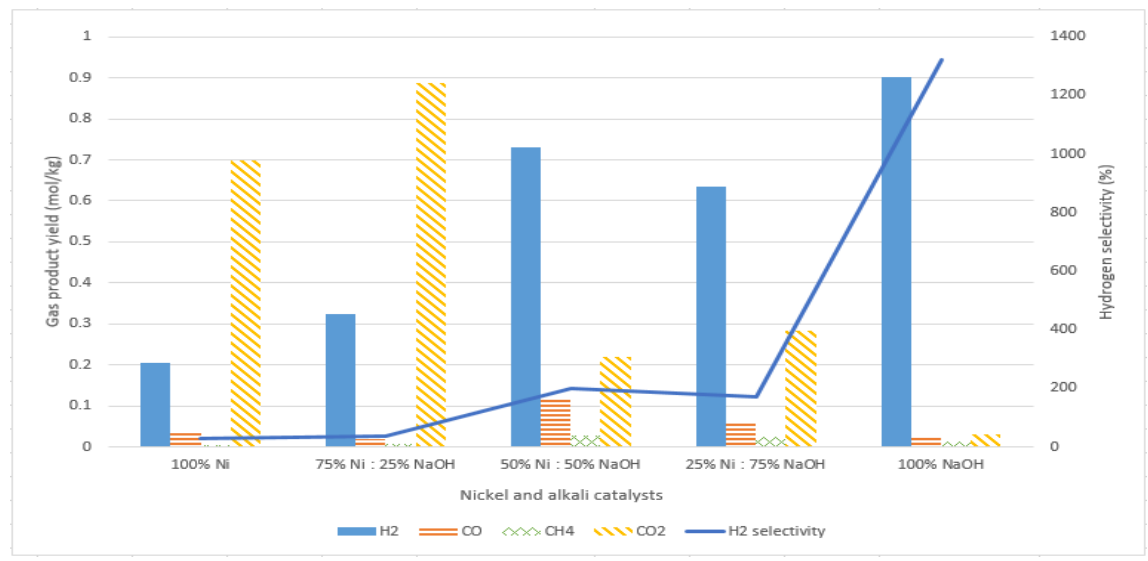

Figure 3: Gas product yield and hydrogen selectivity when $40.5 \mathrm{~g}$ of food waste was gasified for $10 \mathrm{mins}$ at $400^{\circ} \mathrm{C}$ and $22.1 \mathrm{MPa}$ using different amounts of $\mathrm{Ni}$ and $\mathrm{NaOH}$ catalysts. 


\section{Discussion}

This experiment basically investigates the effects of alkali catalysts in the presence of $\mathrm{Ni}$ on $\mathrm{H}_{2}$ production from food waste of multiple constituents. The feedstock containing lignin, cellulose and hemicellulose, carbohydrates, proteins and other species was expected to undergo a complex chemical reaction. However the three major reactions that can occur in the process of catalytic gasification of biomass in supercritical water are as follows;

Steam reforming

$$
\mathrm{C}_{\mathrm{x}} \mathrm{H}_{\mathrm{y}} \mathrm{O}_{\mathrm{z}}+(2 \mathrm{x}-\mathrm{z}) \mathrm{H}_{2} \mathrm{O} \rightarrow \mathrm{xCO}+(2 \mathrm{x}-\mathrm{z}+\mathrm{y} / 2) \mathrm{H}_{2}
$$

Water gas shift reaction

$$
\mathrm{CO}+\mathrm{H}_{2} \mathrm{O} \rightarrow \mathrm{CO}_{2}+\mathrm{H}_{2} \mathrm{O}
$$

Methanation

$$
\mathrm{CO}+3 \mathrm{H}_{2} \rightarrow \mathrm{CH}_{4}+\mathrm{H}_{2} \mathrm{O}
$$

\subsection{Effects of $\mathrm{Ni}$ and alkali catalysts on $\mathrm{H}_{2}$ yield}

A closer look at the results presented in this study gives a clear implication of the combined effects of $\mathrm{Ni}$ and alkali catalysts on the conversion of organic matter to gaseous products and also the WGSR in order to produce more $\mathrm{H}_{2}$. In this study, $\mathrm{Ni}$ was able to enhance the steam reforming reaction in converting the food waste into gaseous products. As a result, there was a significant increase in the $\mathrm{H}_{2}$ yield as compared to when only food waste was gasified in the absence of a catalyst. However, Ni may have a little impact on the WGSR as carbon oxides were not captured and also $\mathrm{H}_{2}$ yield was less compared to results from the addition of $\mathrm{NaOH}, \mathrm{NaHCO}_{3}, \mathrm{KOH}$ and $\mathrm{K}_{2} \mathrm{CO}_{3}$. Also, the addition of $\mathrm{Ca}(\mathrm{OH})_{2}$ to $\mathrm{Ni}$ could not shift the WGSR forward to increase $\mathrm{H}_{2}$ yield because of the unavailability of $\mathrm{Ca}^{+}$to capture $\mathrm{CO}_{2}$. This deficiency is as a result of low decomposition of calcium formates at low supercritical temperatures [36]. The effects of the addition of $\mathrm{Ni}$ and $\mathrm{K}_{2} \mathrm{CO}_{3}$ on the $\mathrm{H}_{2}$ yield is interesting as it differs from results in recent studies by Muangrat et al. [36] when only alkali catalysts were used to gasify glucose at $330^{\circ} \mathrm{C}$ and $13.5 \mathrm{MPa}$. Also in their study, hydroxide alkalis produced more $\mathrm{H}_{2}$ than carbonates/bicarbonate alkalis. The complex constituent of the feed stock and the reaction time in this study could be the reason for the discrepancies in the results between these two studies.

Also, the variation of the amounts of $\mathrm{Ni}$ and $\mathrm{NaOH}$ catalysts in this study highlights the relevance of the WGSR in the SCWG of biomass. From Fig 3, the addition of $1 \mathrm{~g}$ of $\mathrm{NaOH}$ facilitated the conversion of food waste to produce more gaseous products $\left(\mathrm{CO}_{2}\right)$. The initiation of the WGSR also resulted in a significant increase in the $\mathrm{H}_{2}$ yield. Also it is important to note that using equal amount of $\mathrm{Ni}$ and $\mathrm{NaOH}$ produced a higher $\mathrm{H}_{2}$ yield than when $1 \mathrm{~g}$ of $\mathrm{Ni}$ and $3 \mathrm{~g}$ of $\mathrm{NaOH}$ were used. This observation is best explained as a result of the existence of more $\mathrm{CO}$ to react with the abundant $\mathrm{H}_{2} \mathrm{O}(81.5 \%)$ in the system $(50 \% \mathrm{Ni}-50 \% \mathrm{NaOH})$ during the WGSR to produce more $\mathrm{H}_{2}$. That is, although, more than $50 \% \mathrm{of}_{2}$ 
produced during the SCWG of biomass is from the WGSR [9], conversion into gaseous products during the steam reforming reaction is also vital to increase the $\mathrm{H}_{2}$ yield especially when little amounts of $\mathrm{NaOH}$ is used. Furthermore, using $4 \mathrm{~g}$ of $\mathrm{NaOH}$ catalyst produced 4.5 times more $\mathrm{H}_{2}$ gas than when $4 \mathrm{~g}$ of Ni catalyst was used. This further implies that the WGSR is responsible for the increase in $\mathrm{H}_{2}$ yield in this study and $\mathrm{NaOH}$ was effective to support that.

\subsection{Effects of $\mathrm{Ni}$ and alkali catalysts on $\mathrm{H}_{2}$ selectivity}

Poor $\mathrm{H}_{2}$ selectivity has been identified as a factor that hinders $\mathrm{H}_{2}$ production from biomass [14]. $\mathrm{H}_{2}$ selectivity basically indicates a comparison between the amount of $\mathrm{H}_{2}$ produced and the amount of carbon atoms produced. $\mathrm{H}_{2}$ selectivity is therefore calculated by the expression;

$\mathrm{H}_{2}$ selectivity

$$
\% H 2 \text { selectivity }=\frac{\text { moles of } H}{\text { carbon atoms }}\left(\frac{1}{R R}\right) 100
$$

where RR is reforming ratio of feed stock.

In this study, due to the nature of the feed stock, we assumed an RR of 1 since this factor (RR) does not affect the analysis. $\mathrm{H}_{2}$ selectivity was in the sequence, $\mathrm{Ni}-\mathrm{NaOH}>\mathrm{Ni}-\mathrm{KOH}>\mathrm{Ni}-\mathrm{K}_{2} \mathrm{CO}_{3}>\mathrm{Ni}-\mathrm{Ca}(\mathrm{OH})_{2}>\mathrm{Ni}>\mathrm{Ni}-\mathrm{Na}_{2} \mathrm{CO}_{3}>\mathrm{Ni}-$ $\mathrm{NaHCO}_{3}>$ No catalyst. In this study, the predominance of $\mathrm{CO}_{2}$ was a major contributor to the low $\mathrm{H}_{2}$ selectivity in the product gases when $\mathrm{Ni}$ and alkali carbonates/bicarbonates were used. The inability for $\mathrm{CO}_{2}$ to be captured in these reactions is speculated by Muangrat et al. [36] to be a $\mathrm{CO}_{2}$-exchange rather than a $\mathrm{CO}_{2}$-removal process. This hypothesis then implies that the activity of using only $\mathrm{Ni}$ catalyst was able to capture $\mathrm{CO}_{2}$ as compared to when $\mathrm{Na}_{2} \mathrm{CO}_{3}$ and $\mathrm{NaHCO}_{3}$ were added. It also signifies that using Ni may have an influence on the WGSR but minimal as compared to $\mathrm{NaOH}$. A closer look at Fig. 2 shows that the addition of $\mathrm{K}_{2} \mathrm{CO}_{3}$ to $\mathrm{Ni}$ in the reaction could increase the $\mathrm{H}_{2}$ yield during the WGSR but showed a $\mathrm{H}_{2}$ selectivity 2.4 times lesser than when $\mathrm{NaOH}$ and $\mathrm{Ni}$ were used (fig. 2). Furthermore, increasing the amount $\mathrm{NaOH}$ in the reactor showed a decrease in $\mathrm{CO}_{2}$, hence higher $\mathrm{H}_{2}$ selectivity. This observation may be due to the following reactions;

Water gas shift reaction.

$$
\mathrm{CO}+\mathrm{H}_{2} \mathrm{O} \rightarrow \mathrm{CO}_{2}+\mathrm{H}_{2}
$$

$\mathrm{CO}_{2}$-capture reaction for $\mathrm{NaOH}$

$$
\begin{gathered}
\mathrm{CO}_{2}+2 \mathrm{NaOH} \rightarrow \mathrm{Na}_{2} \mathrm{CO}_{3}+\mathrm{H}_{2} \mathrm{O} \\
\mathrm{Na}_{2} \mathrm{CO}_{3}+\mathrm{CO}_{2}+\mathrm{H}_{2} \mathrm{O} \leftrightarrow 2 \mathrm{NaHCO}
\end{gathered}
$$

Decarbonylation tends to favor $\mathrm{H}_{2}$ production via the WGSR, especially when $\mathrm{NaOH}$ is used. This is parallel to Le Chatelier's Principle which implies that the removal of the carbon oxides, in particular $\mathrm{CO}_{2}$, is largely responsible for the increased production of $\mathrm{H}_{2}$ gas [37]. Figs 2 and 3 tend to show the extent of decarbonylation in the various reactions. That is, $\mathrm{H}_{2}$ selectivity could be seen as 
a good indicator to measure the ability of the catalysts to shift the WGSR to the right in order to increase the purity of $\mathrm{H}_{2}$ in the effluent gas.

\section{Conclusion}

SCWG of food waste was carried out using $\mathrm{Ni}$ and alkali catalysts; $\mathrm{NaOH}, \mathrm{KOH}$, $\mathrm{Ca}(\mathrm{OH})_{2}, \mathrm{Na}_{2} \mathrm{CO}_{3}, \mathrm{NaHCO}_{3}$ and $\mathrm{K}_{2} \mathrm{CO}_{3}$. The addition of the alkali catalysts to $\mathrm{Ni}$ influenced the gas yield however no significant distinction was observed between hydroxide catalysts and carbonates/bicarbonate regarding the $\mathrm{H}_{2}$ yield. Furthermore, although the SCWG of food waste in the presence of $\mathrm{Ni}$ and $\mathrm{K}_{2} \mathrm{CO}_{3}$ produced the highest $\mathrm{H}_{2}$ yield, using $\mathrm{Ni}$ and $\mathrm{NaOH}$ gave a 2.4 times higher $\mathrm{H}_{2}$ selectivity. We further gasified food waste using $\mathrm{Ni}$ and $\mathrm{NaOH}$ at different loading ratios. Increase in the amounts of $\mathrm{NaOH}$ in the reactor showed a significant increase in $\mathrm{H}_{2}$ yield and selectivity. However using equal amounts of $\mathrm{Ni}$ and $\mathrm{NaOH}$ produced a higher $\mathrm{H}_{2}$ yield than when $1 \mathrm{~g}$ of $\mathrm{Ni}$ and $3 \mathrm{~g}$ of $\mathrm{NaOH}$ were used. We suspected this observation to be as a result of the Ni catalyst supporting the steam reforming reaction in order to produce more $\mathrm{CO}$ to facilitate the WGSR.

\section{Acknowledgements}

The authors are grateful to Derrick Martin Adjei Sowa, Desmond Ofosu Anim and Philip Nti Nkrumah for their assistance.

\section{References}

[1] Demirbas A., Biofuels sources, biofuel policy, biofuel economy and global biofuel projections. Energy Conversion Management. 49: 2106-16, 2008.

[2] Ni M., Leung D.Y.C, Leung M.K.H, Sumathy K., An overview of hydrogen production from biomass. Fuel Processing Technology, 87: 461-472, 2006

[3] Takeshi F., Takafumi S., Hirokazu S., Yasutomo M., Yasuyoshi I., Masahide S., Naotsugu I., Noboru S., Hydrogen production from the gasification of lignin with nickel catalysts in supercritical water. International Journal of Hydrogen Energy, 32: 699-704, 2007

[4] Liao B., Guo L., Lu Y., Zhang X., Solar receiver/reactor for hydrogen production with biomass gasification in supercritical water. International journal of hydrogen energy. 38: 13038-13044, 2013

[5] Chen J., Lu Y., Guo L., Zhang X., Xiao P., Hydrogen production by biomass gasification in supercritical water using concentrated solar energy: System development and proof of concept. International journal of hydrogen energy, 35: 7134-7141, 2010

[6] Izumizaki Y, Park KC, Yamamura T, Tomiyasu H, Goda B, Fujii Y. Exothermic hydrogen production system in supercritical water from 
biomass and usual domestic wastes with an exploitation of $\mathrm{RuO}_{2}$ catalyst. Progress in Nuclear Energy, 50: 438-42, 2008

[7] Castello D., Fiori L., Supercritical water gasification of biomass: Thermodynamic constraints. Bioresource Technology, 102: 7574-7582, 2011

[8] Cao C., Guo L., Chen Y., Guo S., Lu Y., 2010. Hydrogen production from supercritical water gasification of alkaline wheat straw pulping black liquor in continuous flow system. International journal of hydrogen energy, 36: 13528 - 13535, 2011

[9] Milne T.A., Carolyn C. Evans E., Evans R.J., 2002. Hydrogen form biomass, State of the art and research challenges. International Energy Agency, /H2/TR-02/001, 2001

[10] Azadi P., Farnood R., Review of Heterogeneous Catalysts for Sub and Supercritical Water Gasification of Biomass and Wastes, International Journal of Hydrogen Energy, 36: 9529-9541, 2011

[11] Zhang J. Hydrogen Production by biomass gasification in supercritical water. 2008. Energeia Vol. 19, No. 6

[12] Boukis N., Galla U., Muller H., Dinjus E., Biomass Gasification in supercritical water. Experimental progress achieved with the verena pilot plant. 15 th European Biomass Conference and Exhibition, 2007

[13] Shaw R.W., Thomas B. B., Antony A.C., Charles A.E., Franck E.U. Supercritical Water - A Medium for Chemistry, 2001, Chemical. Engineering News 1991, Dec 23, 26

[14] Azadi P., Khan S., Strobel F., Azadi F., Farnood R., Hydrogen Production from Cellulose, Lignin, Bark and Model Carbohydrates in Supercritical Water using Nickel and Ruthenium Catalysts, Applied Catalysis B: Environmental, 117: 330-338, 2013

[15] Guo Y., Wang S.Z., Xu D.H., Gong Y.M., Ma H.M., Tang X.Y., Review of catalytic supercritical water gasification for hydrogen production from biomass, Renewable and Sustainable Energy Reviews, 14: 334-343, 2010

[16] Jarana M.B.G, Sánchez-Oneto J., Portela J.R., Sanz E.N., Martınez de la Ossa E.J., Supercritical water gasification of industrial organic wastes. Journal of Supercritical Fluids, 46: 329-334, 2008

[17] Byrd A.J., Pant K.K., Gupta R.B., Hydrogen production from glycerol by reforming in supercritical water over $\mathrm{Ru} / \mathrm{Al}_{2} \mathrm{O}_{3}$ catalyst. Fuel 87: 29562960, 2008

[18] Holladay J.D., Hu J., King D.L., Wang Y., An overview of hydrogen production technologies. Catalysis Today 139: 244-260, 2009

[19] Levin D.B., Chahine R., Challenges for renewable hydrogen production from biomass, International journal of hydrogen energy, 35: 4962-4969, 2010

[20] Voll F.A.P, Rossi C.C.R.S., Silva C., Guirardello R., Souza R.O.M.A., Cabral V.F., Cardozo-Filho L., Thermodynamic analysis of supercritical water gasification of methanol, ethanol, glycerol, glucose and cellulose. International journal of hydrogen energy. 34: 9737-9744, 2009 
[21] Yoshida Y, Dowaki K, Matsumura Y, Matsuhashi R, Li DY, Ishitani H, et al. Comprehensive comparison of efficiency and $\mathrm{CO} 2$ emissions between biomass energy conversion technologies e position of supercritical water gasification in biomass technologies. Biomass \& Bioenergy, 25(3): 257272, 2003

[22] Yamaguchi A., Hiyoshi N., Sato O., Bando K.K., Osada M., Shirai M., Hydrogen production from woody biomass over supported metal catalysts in supercritical water. Catalysis Today, 146: 192-195, 2009

[23] Muangrat R., Onwudili J.A., Williams P.T., Reactions of different food classes during subcritical water gasification for hydrogen gas production. International Journal of Hydrogen Energy, 37: 2248-2259, 2012

[24] Ishida Y., Kumabe K., Hata K., Tanifuji K., Hasegawa T., Kitagawa K., Isu N., Funahashi Y., Asai T., Biomass Bioenergy, 33: 8-13, 2009

[25] Okajima I., Shimoyama D, Sako T. Gasification and hydrogen production using high pressure superheated stream in the presence of akali catalyst. Journal of Chemical. Engineering. Japan. 40: 356-364, 2007

[26] Xu X, Matsumura Y., Stenberg J., Carbon-catalyzed gasification of organic feed stocks in supercritical water. Journal of Industrial \& Enineering. Chemistry. Research. 35: 2522-2530, 1996

[27] Kruse A., Henningsen T., Sinag A, Pfeiffer J., Biomass gasification in supercritical water; Influence of the dry matter content and the formation of phenols. Industrial Engineering Chemistry Research. 42: 3711-3717, 2003

[28] Digman B., Kim D.S., Alternative energy from food processing waste Environment. Progress. 27: 524-537, 2008

[29] Azadi P., Syed K.M., Farnood R., Catalytic gasification of biomass model compound in near-critical water. Applied Catalysis A.358: 65-72, 2009

[30] Elliott D.C., Catalytic Hydrothermal Gasification of Biomass. Biofuels, Bioproducts \& Biorefining, 3: 254-265, 2008

[31] Sutton D., Kelleher B., Ross J.R.H., Review of literature on catalysts for biomass gasification. Fuel Processing Technology. 73: 155-173, 2001

[32] Watanabe M, Inormata H, Osada M, Sato T, Adschiri T, Arai K. Catalytic effects of $\mathrm{NaOH}$ and $\mathrm{ZrO}_{2}$ for partial oxidative gasification of nhexadecane and lignin in supercritical water. Fuel, 82: 545-52, 2003

[33] Ikushima Y, Hatakeda K, Sato O, Yokoyama T, Arai M. Acceleration of synthetic organic reactions using supercritical water: non catalytic Beckmann and pinacol rearrangements. Journal of the American Chemical Society, 122(9): 1908-18, 2000

[34] Ikushima Y, Hatakeda K, Sato O, Yokoyama T, Arai M. Structure and base catalysis of supercritical water in the non-catalytic Benz aldehyde disproportionation using water at high temperatures and pressures. Angewandte Chemie International Edition, 40(1): 210-3, 2001

[35] Rice S.F, Steeper R.R, Aiken J.D., Water density effects on homogeneous water-gas shift reaction kinetics. Journal of Physical Chemistry A, 102: 2673-8, 1998 
296 Energy Production and Management in the 21st Century, Vol. 1

[36] Muangrat R., Onwudili J.A., Williams P.T., Influence of alkali catalysts on the production of hydrogen-rich gas from the hydrothermal gasification of food processing waste. Applied Catalysis B: Environmental 100: 440-449, 2010

[37] Onwudili J.A., Williams P.T., Role of sodium hydroxide in the production of hydrogen gas from the hydrothermal gasification of biomass. International journal of hydrogen energy, 34: 5645-5656, 2009 